\title{
Arquétipo e catarse nas narrativas audiovisuais
}

\section{Archetype and catharsis in audiovisual narratives}

\author{
SÍlVIO ANTONIO LUIZ A N Z Za \\ Universidade de São Paulo, Escola de Comunicações e Artes. São Paulo - SP, Brasil.
}

\section{RESUMO}

O clímax em filmes e séries televisivas é construído pela combinação de imagens e sons que impactam emocionalmente a audiência, gerando a catarse. O efeito catártico é peça-chave em gêneros como aventura, western e horror. Este artigo analisa o papel que o arquétipo tem na catarse em narrativas audiovisuais ao operar como acionador de emoções. Articulam-se as teorias sobre catarse (Aristóteles, Jauss) e arquétipos (Jung, Durand) para estabelecer as relações entre esses elementos e entender como operam a partir de exemplos de filmes e séries. Resultados mostram a oposição arquetípica heróimonstro como gatilho emocional nas catarses e a relação entre imagens arquetípicas e contexto sócio-histórico em cenas catárticas.

Palavras-chave: Catarse, arquétipo, narrativa audiovisual, filme, série de TV

\begin{abstract}
Climax in movies and TV series is built by a combination of images and sounds that impact emotionally on the audience generating catharsis. The cathartic effect is essential in genres like adventure, western, and horror. This essay analyzes the role of archetypes as an emotional trigger for catharsis in audiovisual narratives. The article articulates theories about catharsis (Aristotle, Jauss) and archetype (Jung, Durand) to establish the basis of relations among them and to understand how they operate in examples of movies and TV series. Results show the archetypal opposition hero-monster acting as an emotional trigger in catharsis and the relation between archetypical images and historical-social context in cathartic scenes.
\end{abstract}

Keywords: Catharsis, archetypes, audiovisual narratives, movie, TV series

\author{
${ }^{a}$ Pós-doutor em Meios e \\ Processos Audiovisuais na \\ Escola de Comunicações e \\ Artes da Universidade de \\ São Paulo. Pesquisador \\ visitante na School of the Arts, \\ Media, Performance \& Design \\ da York University. Orcid: \\ 0000-0002-4851-4903. E-mail: \\ silvioanaz@hotmail.com
}




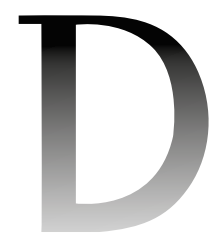

${ }^{1}$ No original: "An act is a series of sequences that peaks in a climactic scene which causes a major reversal of values, more powerful in its impact than any previous sequence or scene". Esta e demais traduções, do autor.

\section{INTRODUÇÃO}

ESTRUTURA NARRATIVA PREDOMINANTE em parte significativa
dos roteiros de filmes e séries que alcançam sucesso global de audiência
fundamenta-se, entre outros elementos, na construção dos momentos de clímax ao longo do enredo. $\mathrm{Na}$ estrutura narrativa normalmente utilizada pelo cinema estadunidense mainstream - em que as produções buscam conquistar amplas audiências globais -, cada ato tem seu ponto de máxima tensão. McKee (2010) destaca que "um ato é uma série de sequências que atinge o auge em uma cena culminante que causa uma importante inversão de valores, mais poderosa em seu impacto do que qualquer outra sequência ou cena prévia" Ele entende que os momentos de clímax numa narrativa audiovisual têm uma gradação de importância e de reversibilidade. O clímax em uma sequência é de moderada importância e em um ato é de grande importância - e ambos são reversíveis. Já o clímax no último ato é, geralmente, o clímax do enredo e da estória, sendo o mais importante de todos e irreversível (McKee, 2010).

Na série televisiva, os momentos de clímax devem ser vistos em relação às suas inserções nos episódios, que dependem do formato que a série adota, se procedimental, com episódios autoconclusivos e independentes, ou serial, com arcos longos e episódios interdependentes. Nas séries serializadas, temos momentos de clímax em cada episódio e o momento de clímax do enredo, geralmente no último episódio; enquanto nas procedimentais temos uma estrutura similar à dos filmes, com clímax a cada ato do episódio e um clímax do enredo nas sequências finais do episódio.

O clímax tem sido explorado também fora dessas formas convencionais, especialmente por séries televisivas caracterizadas pela sua complexidade narrativa (Mittel, 2012), fruto de inovações que tornam as tramas mais desafiadoras e levam a um maior engajamento do público, conforme o demonstrado por Mittel (2012) e Dunleavy (2018), entre outros autores, ao indicarem o uso da serialidade e arcos longos, originalidade conceitual e temporalidade e espacialidade não convencionais como alguns desses novos efeitos especiais narrativos. Um exemplo de deslocamento do momento de clímax é quando ele é usado no começo de episódios ou de filmes, em estruturas narrativas que privilegiam contar o que aconteceu com flashbacks. De toda forma, a construção dos momentos de clímax - seja de uma sequência, de um ato ou do enredo, seja em uma narrativa convencional (ou não) -, é feita normalmente a partir de uma combinação de imagens e sons que buscam explorar ao máximo as emoções do espectador.

Nas narrativas audiovisuais, especialmente naquelas em que predominam ou se misturam os gêneros de aventura, ação, ficção científica, horror e fantasia, o clímax está associado à catarse estética, o que Schaper (1968) considera como 
"o peculiar efeito que apenas a obra de arte poética tem"2 (p. 135). A catarse estética, identificada originalmente por Aristóteles nas suas observações das artes gregas, especialmente do teatro, corresponde a um tipo de envolvimento emocional da audiência que é diferente daquele experimentado na vida real: "a catarse por meio da tragédia corresponde à transformação do que seria doloroso na vida real para o que é profundamente prazeroso quando incorporado na estrutura de um trabalho artístico"3 (Schaper, 1968, p. 140).

Nesse âmbito estético, do sentir em comum que se estabelece entre o espectador e o(s) protagonista(s) do mundo diegético, entendemos que um componente narrativo que se mostra fundamental na construção de cenas que levam à catarse estética é o papel exercido pelo arquétipo - entendido este na sua conceituação contemporânea mais ampla estabelecida especialmente por Jung (1976/2014) e Durand (2002). Na abordagem desses pensadores, o arquétipo, enquanto fenômeno psíquico, materializa-se quando é expresso simbolicamente nas criações artísticas e narrativas, como nos filmes e séries televisivas.

A partir dessas ideias, a tese que aqui exploramos é a de que o arquétipo, ao se manifestar como imagens psíquicas específicas e peculiares cujo conteúdo significante é apreendido pela consciência, participa de forma decisiva na geração da catarse, uma vez que é por meio do conjunto de arquétipos que compõem $\mathrm{o}(\mathrm{s})$ protagonista(s) que o espectador estabelece sua identificação com o(s) ponto(s) de vista e também com as emoções deste(s).

Haveria assim uma estreita conexão entre catarse estética e arquétipos nos momentos de clímax nas narrativas audiovisuais, sendo, consequentemente, as características arquetípicas dos personagens definidoras dos componentes imagéticos e sonoros das cenas de máxima tensão, que são fontes geradoras do impacto catártico na audiência.

Para desenvolver essa tese, apresentamos na primeira parte uma reflexão conceitual sobre a conexão entre a teoria dos arquétipos e a da catarse estética e, na segunda parte, buscamos identificar de que forma a presença de determinados arquétipos potencializa o efeito emocional na audiência em dois exemplos de cenas catárticas: uma no filme No Tempo das Diligências (Ford, 1939) e outra no episódio "Os Espólios da Guerra” (Benioff et al., 2017), da série televisiva Game of Thrones (Benioff et al., 2011-2019).

\section{ARQUÉTIPOS COMO FONTES EMOCIONAIS NAS NARRATIVAS}

Ao desenvolver as bases do conceito contemporâneo de arquétipo, tendo em vista principalmente sua aplicação na psicologia analítica, Jung (1976/2014) estabelece uma inseparável relação entre as emoções e as imagens arquetípicas. 
Na hipótese junguiana, os arquétipos são imagens primordiais, universais e a-históricas localizadas numa camada inferior do inconsciente humano, que ele denominou de inconsciente coletivo (Jung, 1976/2014). Ao emergirem do nível inconsciente do indivíduo para o consciente, os arquétipos são preenchidos por imagens.

A criação das narrativas mitológicas é, nessa perspectiva, o resultado de uma primeira expressão dos arquétipos e das imagens arquetípicas. Durand (2002, p. 63) entende que o mito é uma narrativa fruto de um esboço de racionalização dos arquétipos transformados em ideias e das imagens arquetípicas transformadas em palavras. Desde então, a manifestação dos arquétipos na produção simbólica humana, especialmente nas mitologias, religiões e artes, constituiu um repertório milenar de características e emoções associadas a cada arquétipo, que tem sido amplamente explorado pela produção audiovisual contemporânea.

Mas, enquanto os arquétipos em si são universais e a-históricos, as imagens que os preenchem quando se manifestam - isto é, as imagens arquetípicas são produtos da cultura e do momento histórico vivenciado pelo indivíduo e sua coletividade. Assim, um mesmo arquétipo pode ser preenchido por diferentes imagens, em função da cultura e do contexto histórico. Um bom exemplo disso é o surgimento de uma imagem arquetípica específica de um tipo de herói característico da cultura estadunidense: a do vigilante, que se caracteriza como um tipo de herói que age unicamente de acordo com seus próprios códigos morais, não se submetendo a autoridades, leis ou processos legais que não estejam plenamente de acordo com seus valores pessoais. O herói vigilante vem sendo representado ao longo dos dois últimos séculos por distintas imagens, desde a do cowboy e do pioneiro no Velho Oeste norte-americano - em que a ausência de leis e autoridades estimulava o seu surgimento - até a de personagens contemporâneos como Rorschach, da graphic novel Watchmen, criação de Alan Moore e David Gibbons (1988-1989) - em que as leis e autoridades podem ser um obstáculo para satisfazer o desejo por um certo tipo de justiça feita com as próprias mãos e da forma mais imediata possível.

As imagens que emergem no nível consciente, no entanto, somente são arquetípicas à medida que estejam carregadas de emoções positivas ou negativas. Para Jung (1976/2014), a manifestação de um arquétipo se dá somente quando a imagem ganha numinosidade, isto é, energia psíquica, e se torna dinâmica e significativa o suficiente para impactar o indivíduo. Assim, seguindo no nosso exemplo das imagens arquetípicas do herói vigilante, elas impactam emocionalmente a audiência a partir das características amplas que definem um herói, de qualquer tipo, e pelas particularidades do tipo vigilante.

Há assim - numa dimensão mais ampla - a empatia que a audiência estabelece com as características que em geral definem o herói ficcional, que são: 
autossacrifício ${ }^{4}$, trajetória de transformação (de si próprio e/ou do mundo a sua volta) e, segundo Coogan (2009, p. 77), uma missão altruísta e pró sociedade, o que significa que a luta do herói contra o mal não mira benefícios próprios e sim servir aos códigos morais existentes na sociedade em que se insere. E, numa dimensão mais específica, o herói vigilante também causa empatia graças às suas principais características particulares, que são: não respeitar os limites legais ou de autoridades e exercer a punição aos criminosos imediatamente, sem esperar os processos judiciais.

A conexão entre arquétipos e as emoções sugeridas pelo conceito junguiano ${ }^{5}$ podem ser investigadas também a partir dos avanços da neurociência e da psicologia, especialmente nos estudos de emoções e sentimentos humanos, que acrescentam contribuições importantes para a compreensão do fenômeno.

Ekman (2011) entende que o motivo mais básico e importante para geração das emoções se dá "quando sentimos, justificadamente ou por engano, que algo que afeta seriamente nosso bem-estar, para melhor ou pior, está acontecendo ou prestes a acontecer" (p. 36). Baseado em estudos empíricos com pacientes neurológicos, Damásio (2012) defende a tese de que razão e emoção operam conjuntamente no processo cognitivo, que a emoção auxilia e dialoga com a razão e também transmite informações cognitivas:

o sistema de raciocínio evoluiu como uma extensão do sistema emocional automático, com a emoção desempenhando vários papeis no processo de raciocínio.... A presença obrigatória da emoção no processo de raciocínio pode ser vantajosa ou nefanda, dependendo das circunstâncias da decisão e da história pregressa de quem decide. (Damásio, 2012, Retorno ao erro de Descartes, paras. 5-6)

A imagem arquetípica é interpretada pela audiência a partir da combinação da reflexão racional sobre a imagem e seus significados e da resposta emocional a ela. A tese do trajeto antropológico (Durand, 2002) traz a ideia de que a imagem arquetípica é fruto do imaginário ${ }^{6}$ e um produto da imaginação que opera entre forças contraditórias: em um sentido, as pulsões (internas ao indivíduo) e, no sentido contrário, as coerções (externas ao indivíduo) impostas pelos mundos natural e cultural - trazendo também a ideia de operação simultânea de elementos racionais e emocionais no processo.

Damásio (2012, Emoções, para. 7) enfatiza que "as emoções só são desencadeadas após um processo mental de avaliação que é voluntário e não automático". Afinal, como nos lembra Durand (2013, p. 23), o que distingue o comportamento do Homo sapiens sapiens do de outros animais é que quase toda atividade psíquica humana é indireta, reflexiva, carece da imediatez, segurança
${ }^{4}$ Nesse sentido, o herói aproxima-se da imagem de divindade, mesmo na concepção contemporânea, pois pratica uma abnegação irrestrita: "Trata-se do sacrifício do deus, pois o deus que se sacrifica dá sem retorno" (Mauss \& Hubert, 2005, pp. 106-107).

${ }^{5} \mathrm{O}$ conceito junguiano de arquétipo tem sido testado nas investigações sobre a produção simbólica conduzidas por pensadores como Joseph Campbell (1997) e Gilbert Durand (2002), entre outros, em estudos que mostram a existência de padrões nas narrativas - desde as mitologias mais arcaicas às ficções contemporâneas - $\mathrm{e}$ a redundância de imagens simbólicas e de seus significados, o que sustentaria a tese dos arquétipos proposta por Jung.

${ }^{6}$ Durand (2002) concebe o imaginário como um processo, do qual emergem os elementos simbólicos (arquétipos, imagens arquetípicas, símbolos, estereótipos, mitos) criados pelo Homo sapiens para dar sentido ao mundo. 


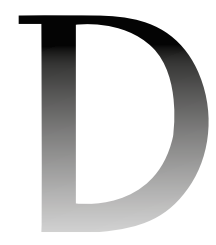

${ }^{7} \mathrm{Tal}$ controle resulta, em nosso entender, no fato das emoções associadas à imagem arquetípica - e, portanto, à manifestação do arquétipo não serem uniformes ao longo da narrativa. Isto é, o medo ou a raiva associada à manifestação do monstro, por exemplo, varia em função dos estímulos e situações colocadas pela narrativa, conforme interpretadas pela audiência.

${ }^{8} \mathrm{Na}$ classificação durandiana, além do regime diurno há o regime noturno das imagens, no qual as imagens simbólicas buscam eufemizar a morte e o tempo, tornando-os aceitáveis. Nessa classificação, predominariam as lógicas da harmonização dos opostos e do diálogo entre eles. e univocidade do instinto, sendo a razão no sapiens resultado dessa mediação neuropsicológica. Para o neurocientista português, as emoções são resultado de um processo avaliatório mental, que impacta no corpo humano, como na mudança na cor da pele (ruborização), na postura corporal e na expressão facial, e no próprio cérebro (alterações mentais), e que operamos cognitivamente com um filtro reflexivo e avaliador que controla as variações nas intensidades das emoções (Damásio, 2012) ${ }^{7}$.

Assim, na fruição da narrativa, a identificação de um arquétipo se daria de forma racional e emocional quase que simultaneamente, à medida que no processo cognitivo são acionados elementos da memória, fruto do conhecimento e da experiência do indivíduo - informações que o levam a conceitualmente identificar o herói ou o monstro, por exemplo -, o que provocaria uma reação impulsiva, funcionando a manifestação do arquétipo como um estopim para a reação emocional da audiência.

Assim, o arquétipo do herói, por exemplo, não importa a imagem arquetípica que a imaginação humana criou para expressá-lo (Gilgamesh, Hércules, Mahyra, Chibinda Ilunga, Batman etc.), é identificado e sentido pelo indivíduo por meio da projeção que ele faz a partir de sua psique da imagem primordial, universal e atemporal do herói no mundo. Assim, o mesmo arquétipo, embora possa ser representado por diferentes imagens, é identificado e sentido de forma universal e atemporal, transcendendo fronteiras culturais, religiosas, étnicas e históricas, e acionando as mesmas emoções coletivamente. Há nesse processo também uma participação da subjetividade, à medida que determinados elementos da narrativa se associam ao conhecimento e à experiência particular e/ou visão de mundo do indivíduo, que reconhece assim traços de si mesmo na imagem arquetípica do herói - correspondam eles à realidade ou não - e acaba por sentir determinadas emoções acionadas por esse arquétipo.

Tomemos como exemplo a oposição arquetípica herói-monstro, integrante da arquetipologia durandiana. Na classificação proposta por Durand (2002), oriunda de um amplo levantamento das imagens simbólicas produzidas por várias culturas ao longo da história e fundamentada na ideia de que a produção simbólica busca enfrentar as angústias da finitude e do devir, a oposição arquetípica herói-monstro insere-se na lógica de vencer a morte e o tempo que Durand classificou como regime diurno das imagens. Nele, prevalecem as ideias de oposição, combate e separação/distinção, em que os arquétipos existem como duas faces de uma mesma moeda, pois sem um o outro não está presente, como vemos nos grandes arquétipos alto-baixo, claro-escuro e puro-manchado, que compõem o regime diurno ${ }^{8}$. Nessa perspectiva, a manifestação do arquétipo do herói se dá sempre em oposição a do monstro, sendo geralmente aquele 
valorizado positivamente e este negativamente. Para tanto, há um processo de construção da narrativa que leva a essas valorizações que impactam nas emoções positivas e negativas que a audiência sente.

Vogler (2015), a partir de uma perspectiva mais pragmática voltada ao processo de criação e avaliação dos roteiros para cinema e TV, já apontava a importância das reações corporais na fruição das narrativas e defende a ideia de que elas são indicadores da qualidade daquilo que se está lendo ou assistindo. No entanto, independentemente da qualidade da criação das imagens que preencherão os arquétipos, estes por si só geram determinadas emoções e sua manifestação na narrativa significa o acionamento de determinadas sensações na audiência.

É preciso fazer aqui uma distinção entre emoção e sentimento, pois nem todos os sentimentos são oriundos de emoções, segundo Damásio (2012). Enquanto uma emoção corresponde a "um conjunto das alterações no estado do corpo associadas a certas imagens mentais que ativaram um sistema cerebral específico", um sentimento a partir de uma emoção é a experiência dessas alterações corporais em justaposição com as imagens mentais que iniciaram o ciclo (Sentimentos, para. 3).

Ele entende que há dois grupos de sentimentos para os humanos: o sentimento de fundo e o sentimento emocional. O primeiro, que é o mais presente ao longo da vida, diz respeito à sensação de existir e não é nem demasiado positivo nem demasiado negativo, pois ocorre entre as emoções. O sentimento emocional, que aqui nos interessa, segundo Damásio (2012), é aquele que sentimos como resposta a estados corporais correspondentes às emoções (felicidade, tristeza, medo etc.), isto é, quando sinais neurais e químicos agem no corpo em resposta a estímulos instintivos e conscientes, ou como resposta a estados mentais que simulam as emoções, isto é, que recorrem a "mecanismos neurais que nos ajudam a sentir 'como se' estivéssemos passando por um estado emocional, como se o corpo estivesse sendo ativado e alterado" (O corpo como teatro das emoções, para. 1).

Retomando a conexão arquétipos-emoções proposta por Jung, Neumann (1999) entende que o arquétipo se constitui em um processo energético na psique que resulta em emoções positivas e negativas que movem e animam o indivíduo: "sua dinâmica exerce pressão irresistível e determina o comportamento humano (inconscientemente), de acordo com leis, e independentemente das experiências de cada indivíduo" (p. 20). O arquétipo leva a um estado de comoção biopsíquica, influenciando a disposição, inclinações, tendências, opiniões, intenções e interesses do indivíduo, além da consciência e do intelecto (p. 20). Relacionando tal perspectiva com a de Damásio (2012), supomos que os arquétipos operariam então no acionamento dos sentimentos emocionais. Antunes (2016) fala de "gatilhos emocionais arquetípicos" que 
seriam acionados pelas narrativas fílmicas e levariam a audiência a estabelecer empatia com os personagens. Assim, no âmbito das narrativas, dada a associação intrínseca entre imagens arquetípicas e emoções, a materialização dos arquétipos nas criações ficcionais operaria como um estopim emocional positivo ou negativo na audiência, com impactos corporais ou como simulação no âmbito mental. A empatia com o herói e a repulsão em relação ao monstro são exemplos clássicos, ainda que simplificadores, desse processo.

No caso da narrativa audiovisual, a imagem arquetípica acionadora das emoções é construída basicamente através da mise-en-scène e da trilha sonora. A partir dessas fontes de imagens icônicas, sonoras, musicais e verbais, construímos imagens mentais, que em alguns casos são arquetípicas, à medida que preenchem determinado arquétipo projetado no mundo real ou imaginado e que provocam um sentimento emocional no indivíduo, assim como numa coletividade. Geralmente, em cenas ou sequências de cenas apresentadas normalmente no final de cada ato e, especialmente, na parte de desenlace do ato final, o impacto emocional torna-se crescente e significativo a ponto de causar catarse na audiência. Para melhor entender tal processo, é preciso refletir sobre como os arquétipos contribuem para o processo catártico nas narrativas.

\section{CATARSE COMO EMOÇÃO ACIONADA PELOS ARQUÉTIPOS}

A fruição das narrativas audiovisuais se dá com variações emocionais determinadas pela contribuição que os elementos visuais, sonoros e textuais do filme ou episódio dão para a construção das imagens nas mentes da audiência. As imagens arquetípicas - aquelas que preenchem determinado arquétipo acionado pela narrativa e projetado no consciente de cada indivíduo - são as capazes de gerar emoções que impactam no sujeito, fazendo-o senti-las no corpo e na mente ou, de forma simulada, unicamente nesta.

Pressupomos, assim, que a imagem arquetípica pode surgir de forma imediata, às vezes como uma epifania, no processo de fruição, ou ser fruto de uma construção alimentada pelos elementos de várias cenas e sequências. No primeiro caso, como revelação imediata, ela surge a partir de um único simbolismo em uma cena - cuja fonte pode ser a imagem de um personagem ou de um lugar, uma trilha sonora, uma palavra ou uma combinação desses elementos - e torna-se imediatamente reveladora do arquétipo que está preenchendo. Isso ocorre porque uma cena é suficiente para a audiência identificar a imagem arquetípica como manifestação ou percepção da natureza ou do significado essencial do arquétipo, apreender intuitivamente seu significado simbólico e ter os sentimentos emocionais correspondentes. No segundo caso, como construção, ela é desenvolvida 
pouco a pouco na mente da audiência a partir de um conjunto de cenas que trazem informações que compõem a construção dos sentimentos emocionais do espectador em relação ao arquétipo que se manifesta.

Bons exemplos dessas duas possibilidades aparecem na série televisiva Game of Thrones (Benioff et al., 2011-2019). A narrativa centra-se na disputa político-militar pelo Trono de Ferro dos Sete Reinos, mostrando intricados jogos de poder, alianças, traições e conflitos entre dinastias que disputam o trono. Uma das principais características da estratégia narrativa é a multiplicidade de pontos de vista que leva a se abrirem várias janelas para a audiência, com o espectador podendo identificar-se com mais de um protagonista que apresenta características arquetípicas do herói. É o caso do personagem Eddard "Ned" Stark (Sean Bean), líder de uma das dinastias. Sua imagem arquetípica como herói é construída ao longo dos nove primeiros episódios, até sua morte. Paulatinamente, são associados à sua imagem valores como lealdade, honra, bondade e justiça, e características como astúcia e coragem, além da atitude de autossacrifício. Assim, ao chegarmos ao sétimo episódio da série, uma das imagens que preenchem a manifestação do arquétipo do herói em Game of Thrones (Benioff et al., 2011-2019) é a de Ned Stark, que foi construída pouco a pouco ao longo dos seis episódios anteriores. As aparições de Stark impactam emocionalmente a audiência, que geralmente sente satisfação com suas ações de justiça, lealdade e coragem; tristeza e raiva quando ele é injustamente condenado; e surpresa e raiva quando ele é morto.

Enquanto uma das imagens arquetípicas do herói é construída ao longo de vários episódios, uma das imagens arquetípicas do monstro é dada de forma imediata, isto é, apresentada em uma única cena logo na primeira sequência do primeiro episódio. Nela vemos a aparição de criaturas sobrenaturais mortas-vivas que atacam guardas que fazem parte da Patrulha da Noite, encarregada de tomar conta de uma imensa muralha de gelo para evitar a invasão dessas criaturas e outras ameaças aos Sete Reinos. Os sentimentos emocionais gerados por essa imagem arquetípica do monstro são geralmente as de medo e repulsa ${ }^{9}$.

As imagens arquetípicas geram diferentes graus de impacto emocional positivos e negativos. As narrativas audiovisuais ficcionais de sucesso são repletas de cenas e sequências que atendem a certas expectativas da audiência e geram nesta um efeito emocional catártico.

A noção de catarse - termo que, na sua origem, significa purgação, quando usado de forma neutra ou na medicina, e purificação, quando usado no sentido moral ou religioso - relacionada às obras da criação artística ${ }^{10}$ é adotada por Aristóteles na obra Poética (século 4 a.C.) enquanto ele desenvolve sua reflexão sobre a tragédia:

\footnotetext{
${ }^{9}$ Para Paul Ekman (2011), há pelo menos sete emoções universais: satisfação, tristeza, medo, raiva, desprezo, repulsa e surpresa.

${ }^{10} \mathrm{O}$ conceito de catarse aparece na cultura grega nos pensamentos de Demócrito, Platão e Pitágoras, que antecedem Aristóteles, com as acepções de purificação e purgação voltadas à medicina, às artes e à moral (Freire, 1979, p. 1).
} 


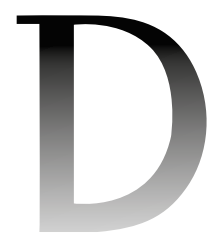

A tragédia é a imitação de uma ação elevada e completa, dotada de extensão, numa linguagem embelezada por formas diferentes em cada uma das suas partes, que se serve da ação e não da narração e que, por meio da compaixão e do temor, provoca a purificação [ênfase adicionada] de tais paixões. (Aristóteles, 350 a.C./2018, pp. 47-48)

Ao considerar a catarse como a finalidade da tragédia, Aristóteles entende, segundo Santoro (2007), que a "provocação e a transformação das emoções humanas nas obras poéticas é algo tanto ou até mais importante que a expressão de valores e conteúdos morais" (p. 10).

Para Aristóteles (350 a.C./2018), a catarse é um elemento próprio da tragédia e é a capacidade desta de levar à catarse que define sua qualidade:

O temor e a compaixão podem, realmente, ser despertados pelo espetáculo e também pela própria estruturação dos acontecimentos, o que é preferível e próprio de um poeta superior. É necessário que o enredo seja estruturado de tal maneira que quem ouvir a sequência dos acontecimentos, mesmo sem os ver, se arrepie de temor e sinta compaixão pelo que aconteceu; isto precisamente sentirá quem ouvir o enredo do Édipo. Mas produzir este efeito através do espetáculo revela menos arte e está dependente da encenação. E os que, através do espetáculo, não produzem temor mas apenas terror, nada têm de comum com a tragédia: não se deve procurar na tragédia toda a espécie de prazer, mas a que lhe é peculiar. E, uma vez que o poeta deve suscitar, através da imitação, o prazer inerente à compaixão e ao temor, é evidente que isso deve ser gerado pelos acontecimentos. (pp. 63-64)

Para Schaper (1968), a catarse aristotélica refere-se a um conceito estético, ao peculiar efeito que apenas a arte provoca nas pessoas: a catarse "corresponde ao envolvimento emocional de um tipo diferente daquele experimentado no impacto emocional de eventos reais. . . . O prazer derivado dos trabalhos artísticos de

${ }^{11}$ No original: "It accounts for emotional involvement of a different kind from that experienced in the emotional impact of real events... Enjoyment derived from works of art of any kind exhibits a shift of levels, from the ordinary to the aesthetic". qualquer tipo exibe uma mudança de nível, do ordinário para o estético"11 (p. 140).

Paskow (1983) segue na mesma linha de Schaper e vê a catarse aristotélica como um fenômeno no âmbito da experiência estética:

Catarse estética é uma purificação no espectador da tragédia de suas capacidades de experimentar pena e medo; é também uma experiência prazerosa. . . É uma resposta emocional apropriada imediata a uma sequência de eventos dramáticos e para as mais significantes possibilidades humanas e individuais do espectador. O termo "catarse" portanto denota ter uma referência interna e externa: talvez seja 
por isso que Aristóteles escolheu justamente essa palavra que tem tanto significações médica, moral e religiosa ${ }^{12}$. (pp. 61-64)

Para Aristóteles, as emoções sentidas na fruição da narrativa são criadas. Schaper (1968) afirma que, para o pensador grego, "não assumimos ou copiamos simplesmente as emoções que nos são ficcionalmente apresentadas; respondemos à estrutura total do evento ficcional com emoções de nós mesmos, não com emoções obtidas por 'contágio"'13 (p. 142). Nessa perspectiva, a experiência emocional catártica relaciona-se à fruição da narrativa quando a audiência se coloca empaticamente no lugar do protagonista para sentir o que ela imagina que ele está sentindo.

Tal experiência emocional, segundo Jauss (1974),

ocorre quando o espectador da tragédia pode se colocar a si mesmo tão completamente na posição do herói em seu imerecido sofrimento de forma que ele sente por aquele herói o que ele poderia de outra forma apenas sentir por ele próprio ${ }^{14}$. (pp. 287-288)

O pensador alemão entende que a experiência da catarse pelo espectador corresponde a dois momentos: o primeiro, da liberação da audiência em relação ao seu mundo ordinário - a negação da vida cotidiana - e o ingresso no universo ficcional da narrativa, o que só é possível através da identificação do espectador com o herói que protagoniza a ação narrativa; o segundo momento, em que ele também deve se liberar do mundo ficcional, quando, embora sinta o que o protagonista deveras sente, sua reação deve se dar dentro de limites aceitáveis, em um estado de compostura desejável (Jauss, 1974, p. 288).

A resposta emocional da catarse parece ser proporcional à situação imaginária vivenciada pelo protagonista com o qual o espectador se identifica, normalmente um personagem que traz características do arquétipo do herói. Paskow (1983) vê "o protagonista como competidor psicológico que nos ajuda, os espectadores, a explorar em nossas emoções e imaginação (assim como com nosso intelecto) uma parte de nós mesmos que ordinariamente evitamos ou reprimimos"15 (p. 66). As consequências de tal exploração podem ser terríveis, ainda segundo Paskow, "mas ela é frequentemente libertadora, até mesmo revigorante"16 (p. 66).

Dentro desses pressupostos, parece-nos que a manifestação do arquétipo do herói é o principal gatilho emocional do efeito catártico, que emerge em situações geradoras de emoções extremas. No caso das narrativas audiovisuais, a experiência emocional catártica acionada pelas imagens arquetípicas do herói tem suas fontes, como já mencionamos, numa combinação de elementos, principalmente da mise-en-scène e da trilha sonora.

\footnotetext{
${ }^{12}$ No original: "Aesthetic catharsis is a purification in the spectator of tragedy of his capacities to experience pity and fear; it is also a pleasurable experience. ... It is an emotional response appropriate at once to a sequence of dramatic events and to the spectator's most significant individual and human possibilities. The term 'catharsis' therefore is meant to have an internal and external reference; perhaps that is why Aristotle chose just that word, which has both medical, moral, and religious significations".

${ }^{13}$ No original: "we do not simply take over or copy the emotions which are fictionally presented to us; we respond to the total structure of fictional events with emotions of our own, not with emotions caught by 'infection"'.

${ }^{14}$ No original: "catharsis occurs when the spectator of tragedy can place himself so completely in the position of undeservedly suffering hero that he fears for that hero what he would otherwise only fear for himself".
}

\footnotetext{
${ }^{15}$ No original: "the protagonist as psychological competitor helps us, the spectators, to explore in our emotions and imagination (as well as with intellects) a part of ourselves that we ordinarily avoid or altogether repress".

${ }^{16}$ No original: "But it is often liberating, even exhilarating".
} 
Cenas em que a imagem arquetípica do herói aparece em confronto com as forças antagônicas a ele - e aos valores e princípios morais que ele representa são normalmente catárticas e muitas vezes o ponto alto das catarses das narrativas audiovisuais. É interessante notar que os mesmos arquétipos acionam sempre as mesmas emoções, independentemente da imagem arquetípica utilizada ou do contexto social e histórico em que a narrativa se insere. Para melhor entender esse fenômeno, vejamos a comparação de cenas catárticas em produções audiovisuais consagradas.

No Tempo das Diligências (Ford, 1939), considerado um dos mais famosos filmes do gênero western, traz uma sequência de cenas catárticas nos trinta minutos finais do filme: um nascimento, um ataque dos Apaches, uma prisão, um tiroteio protagonizado pelo herói principal e uma fuga romântica para $o$ México. O uso de clímax após clímax é uma das particularidades dos filmes de John Ford, que aparece também em Rastros de Ódio (Ford, 1956), por exemplo.

Uma das sequências catárticas na parte final de No Tempo das Diligências (Ford, 1939) mostra os nativos Apaches em uma prolongada perseguição e ataque à diligência de um grupo composto por figuras marginais e do establishment como uma prostituta, um delegado, um banqueiro, um médico alcoólatra e um fugitivo da prisão, entre outros, que estão indo em direção ao Velho Oeste e acabam emboscados. A sequência culmina com a aparição no último minuto da cavalaria do exército dos Estados Unidos para salvar os viajantes e afugentar os indígenas.

A sequência estabelece a típica oposição arquetípica herói-monstro. $\mathrm{O}$ arquétipo do herói é preenchido pelas imagens dos viajantes, especialmente pela imagem do personagem Ringo Kid (John Wayne), e pelas imagens da cavalaria. A imagem arquetípica do monstro é preenchida pelos Apaches, os outros aos olhos dos viajantes, vistos como selvagens e cruéis, a ponto de os viajantes preferirem estar mortos a serem capturados por eles. Parte das representações construídas são estereotipadas, especialmente as dos Apaches, na medida em que há uma construção superficial desses personagens, identificando-os como uma ameaça por estarem fora de suas reservas e comandados por Gerônimo, um dos mais importantes líderes militares indígenas da América do Norte, que era contrário aos acordos de confinamento dos nativos às reservas.

Mostrar os viajantes em perigo ante o ataque dos Apaches (Figura 1) - isto é, o herói ameaçado pelo monstro - inicia o processo de catarse, pois a identificação do espectador com os viajantes o faz sofrer e, estimulado pelo mundo ficcional, simular as emoções de medo e raiva em si próprio. Para superar o medo e satisfazer a raiva, alcançando assim a catarse, é esperado que o herói sobreviva e suplante ou mate o monstro. E é isso que a sequência de cenas traz, especialmente quando, no momento em que tudo parece perdido (Figuras $2 \mathrm{e} 3$ ), 
surge a cavalaria (Figura 4) para salvar os viajantes, acionando o sentimento de satisfação na audiência. A catarse se completa, assim, como uma experiência prazerosa e libertadora para o espectador, que vê os heróis, com os quais se identifica e por quem tem empatia, superarem o monstro, pelo qual têm aversão.

\section{Figura 1}

Cena de No Tempo das Diligências 1

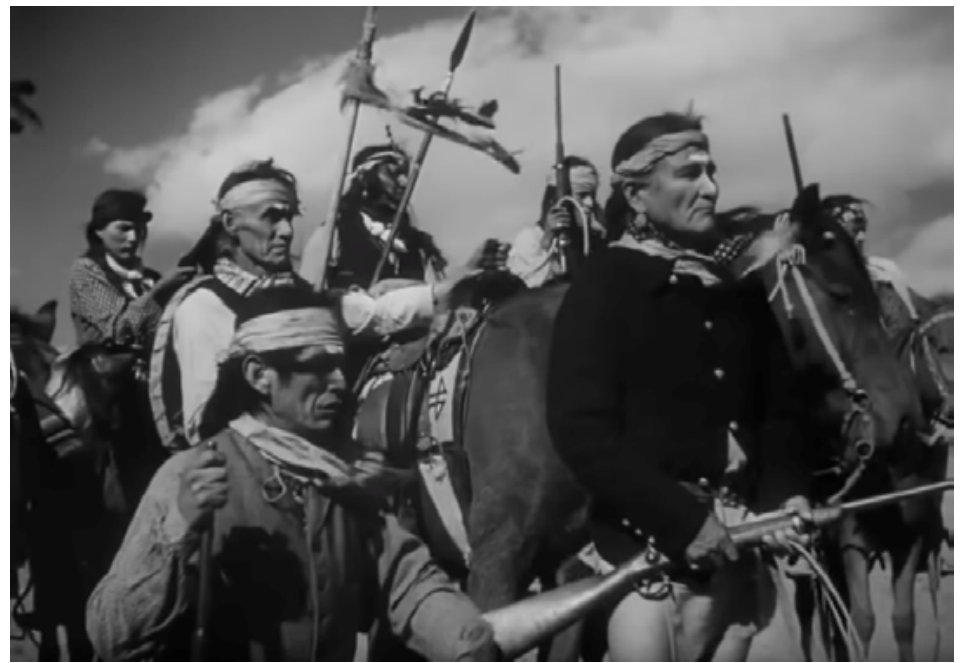

Nota. Início da sequência catártica mostra os Apaches, sob a liderança de Gerônimo, aguardando em uma emboscada a passagem da diligência. Fotograma do filme.

\section{Figura 2}

Cena de No Tempo das Diligências 2

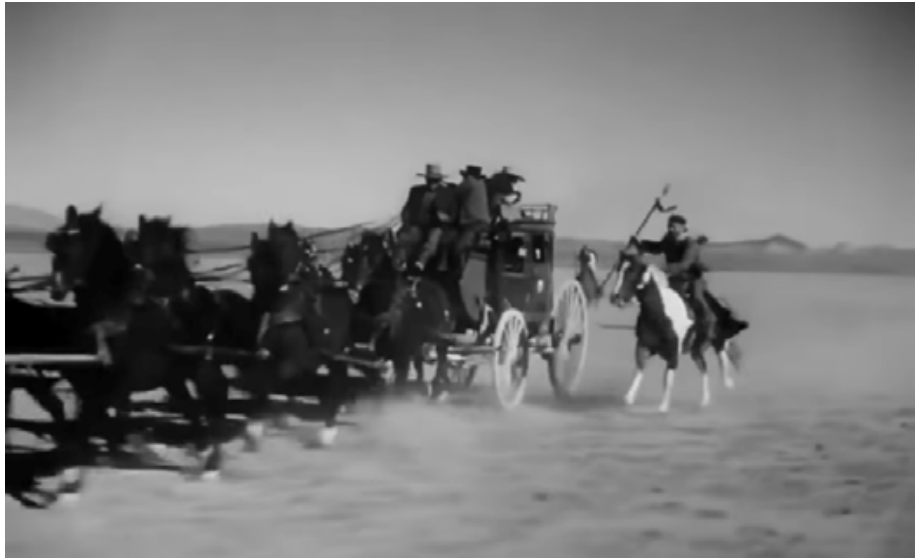

Nota. Ataque dos Apaches à diligência. O processo catártico atinge o ponto alto da tensão com a ameaça iminente aos heróis imposta pelos monstros. Fotograma do filme. 


\section{Figura 3}

Cena de No Tempo das Diligências 3

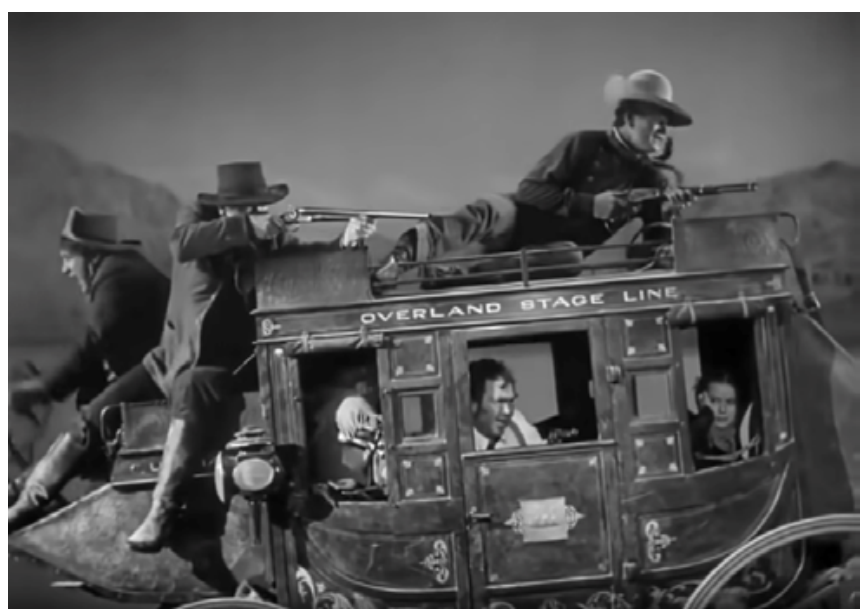

Nota. Heróis em ação - nesse caso o delegado, à esquerda, e o fugitivo Ringo Kid (John Wayne) na parte superior da diligência. A cena, a despeito da aparição dos heróis, não leva ao alívio do espectador e mantém a tensão, pois, apesar da ação heroica, o risco aumenta à medida que eles ficam sem munição. Fotograma do filme.

\section{Figura 4}

Cena de No Tempo das Diligências 4

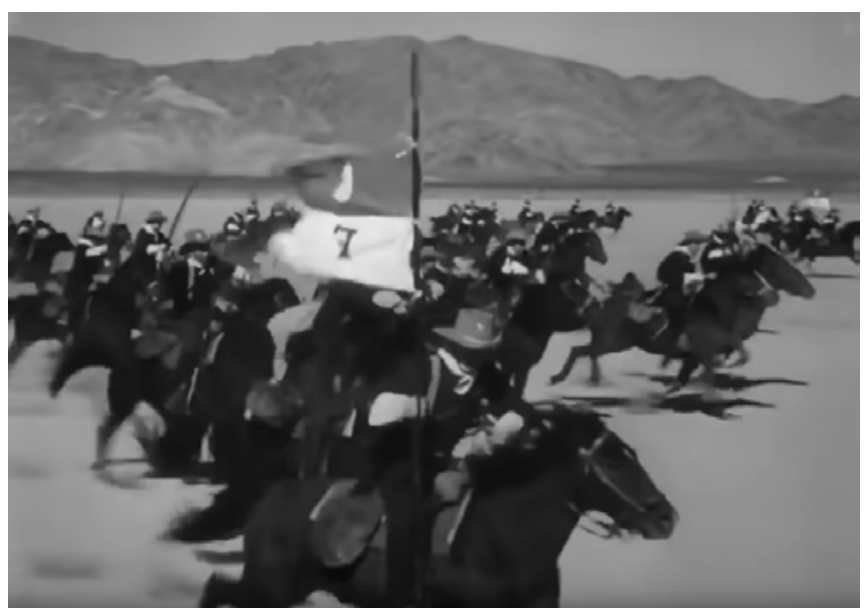

Nota. Chegada da cavalaria; o processo catártico se conclui à medida que os soldados afugentam os Apaches. Fotograma do filme.

É importante ressaltar que o contexto sociocultural desde a época de lançamento de No Tempo das Diligências (Ford, 1939) mudou significativamente e os papéis de herói e monstro atribuídos na narrativa são agora questionáveis. 
No entanto, mesmo que os papéis sejam trocados, os arquétipos e emoções acionadas por eles permanecem. Voltaremos a isso adiante em comparação com uma outra sequência catártica que propomos analisar e que mostra justamente uma inversão nas imagens arquetípicas em relação ao que vimos em No tempo das Diligências (Ford, 1939).

Em Game of Thrones (Benioff et al., 2011-2019), uma das sequências catárticas mais importantes acontece no episódio "Os Espólios da Guerra" (Benioff et al., 2017). Nela, há o confronto entre o exército da família Lannister e seus aliados e os exércitos comandados por Daenerys Targaryen, incluindo os guerreiros nômades Dothraki e dragões. Mais uma vez a oposição arquetípica herói-monstro funciona como principal gatilho emocional. Daenerys e seus aliados representam a imagem arquetípica do herói, enquanto os Lannisters e seus aliados, a do monstro. Aqui, consideramos que a narrativa apresenta personagens arquetípicos e não estereotipados, já que construiu ao longo dos 63 episódios anteriores perfis psicológicos e sociológicos aprofundados dos protagonistas, mostrando suas virtudes e seus vícios, bem como suas contradições, aproximando-os do que é o humano em sua complexidade.

A sequência de cenas (Figuras 5 a 10) mostra os exércitos comandados por James Lannister não só tendo que enfrentar os liderados por Daenerys, como principalmente sendo surpreendidos pelo ataque dos dragões, que dizimam com seu fogo centenas de soldados. As emoções acionadas pelos arquétipos ao longo da batalha são as de raiva - a cena caracteriza um possível momento de vingança -, medo - à medida que Daenerys e o dragão que monta correm perigo durante o confronto - e satisfação - pela vitória alcançada pelo herói. É interessante notar dois pontos aqui: (i) a satisfação da audiência que se identifica e tem empatia por Daenerys e aversão aos Lannisters e seus aliados vem principalmente quando o dragão queima vivos centenas de seres humanos associados a imagens arquetípicas do monstro; (ii) o preenchimento do arquétipo do herói por imagens tradicionalmente associadas ao monstro, como a dos bárbaros (Dothrakis) e do próprio dragão - a inversão, no entanto, é apenas no nível das imagens, já que na essência ela mantém a oposição entre bons e maus, nas quais a audiência tende a ter predominantemente empatia e identificação pelos primeiros, independentemente da imagem que eles assumam (outsiders, renegados, selvagens, outros etc.). 


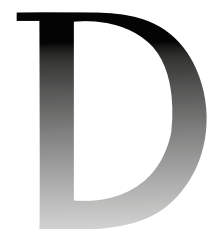

\section{Figura 5}

Cena de Game of Thrones 1

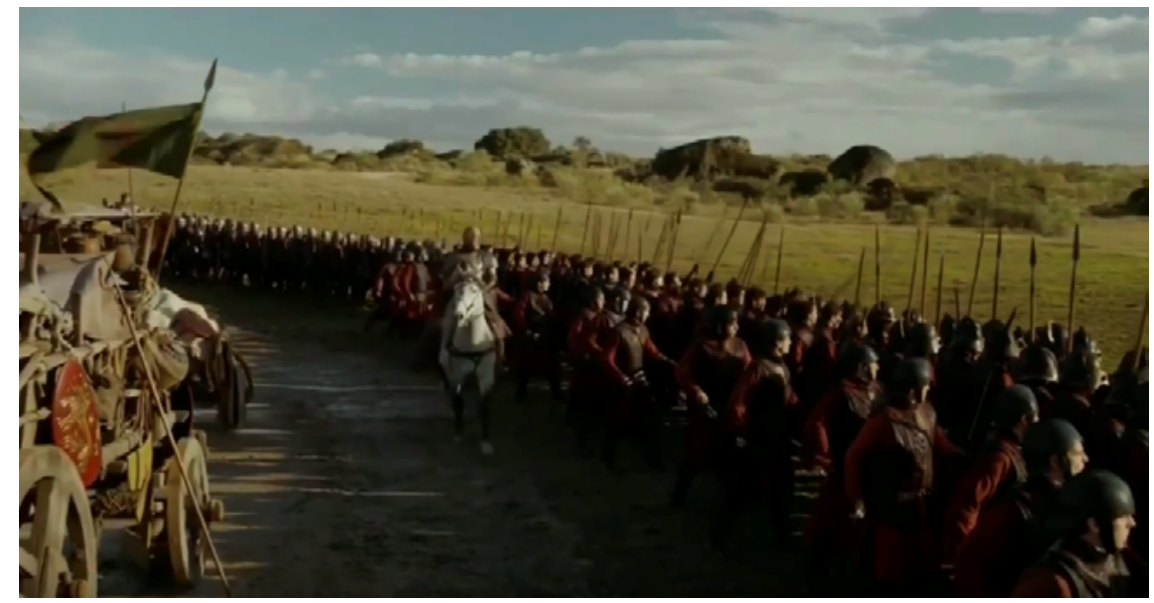

Nota. Exército dos Lannisters e seus aliados. Imagem da série.

\section{Figura 6}

Cena de Game of Thrones 2

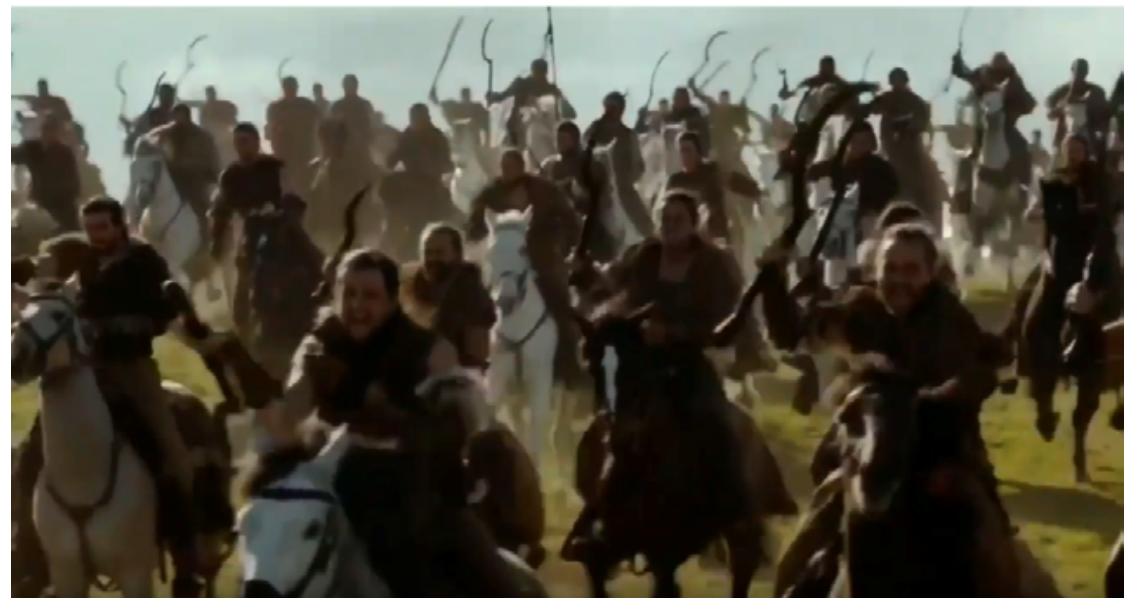

Nota. Ataque dos Dothraki, iniciando o processo catártico, à medida que preenchem o arquétipo do herói. Imagem da série. 


\section{Figura 7}

Cena de Game of Thrones 3

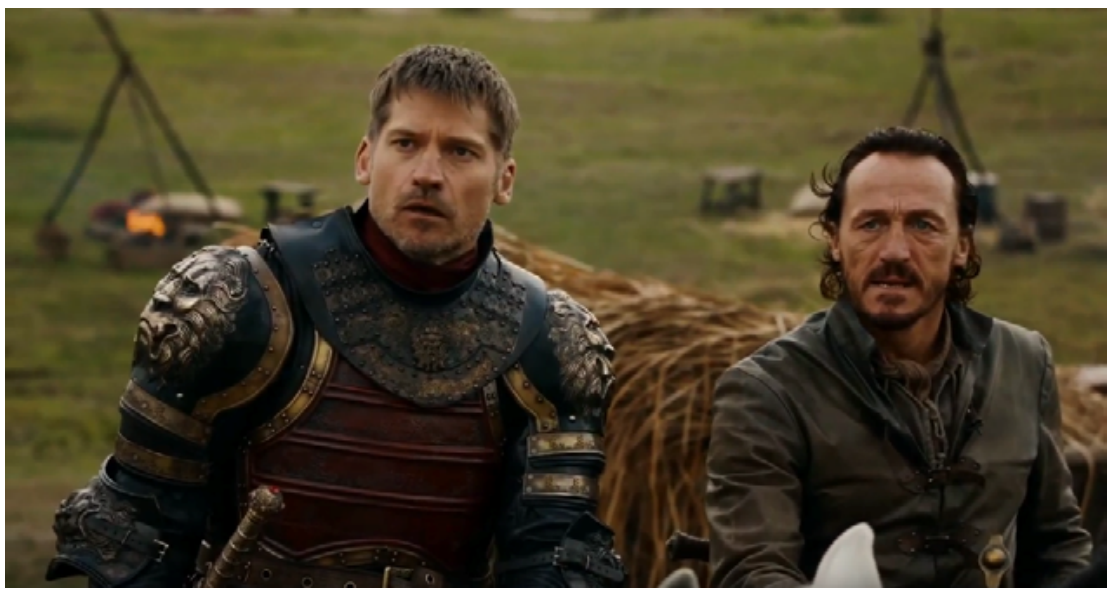

Nota. James Lannister (dir.) espantado ao ver algo. A cena sinaliza que o herói possui recursos que surpreendem o monstro. Imagem da série.

\section{Figura 8}

\section{Cena de Game of Thrones 3}

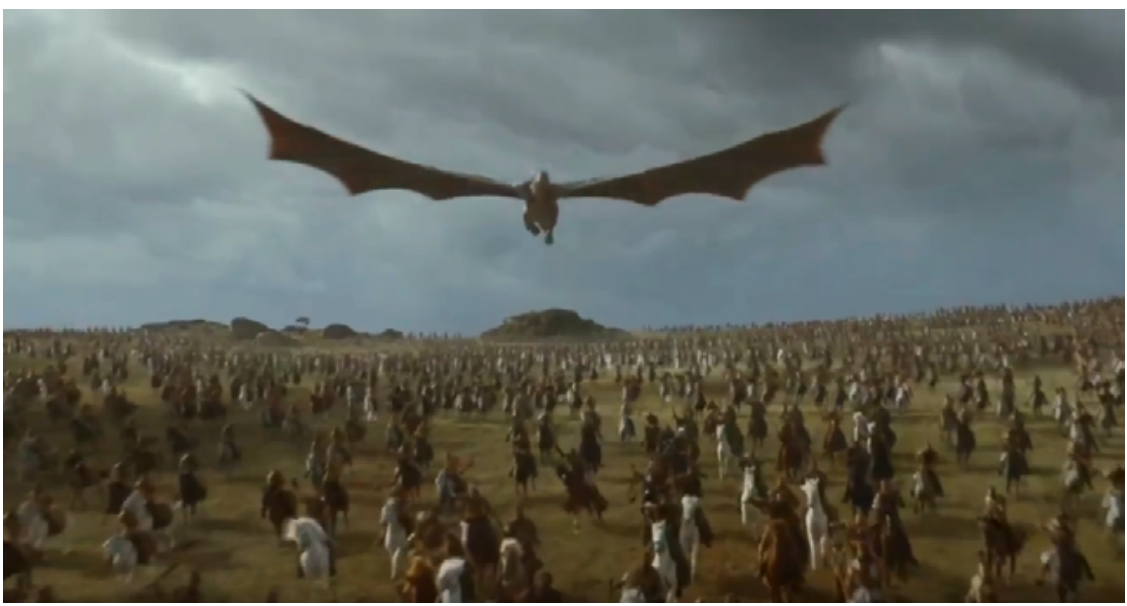

Nota. A surpresa se revela: o ataque do dragão mostra que o herói tem uma força desproporcional (sobre-humana) ao monstro. Imagem da série. 


\section{Figura 9}

Cena de Game of Thrones 4

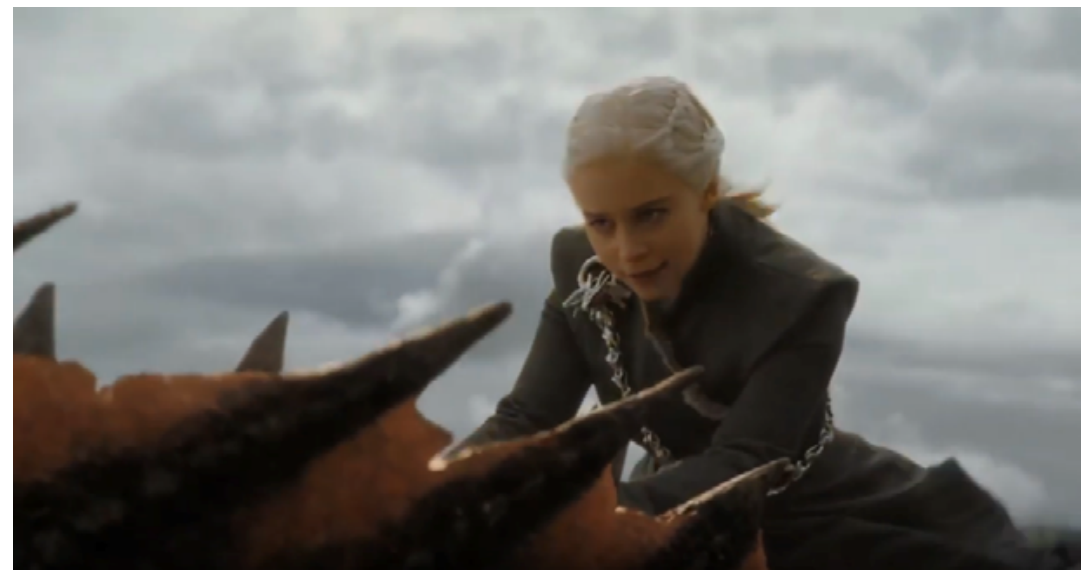

Nota. Daenerys comandando o ataque e montando o dragão; é um dos pontos altos do processo catártico por ser a primeira aparição de um dos heróis principais. Imagem da série.

\section{Figura 10}

Cena de Game of Thrones 5

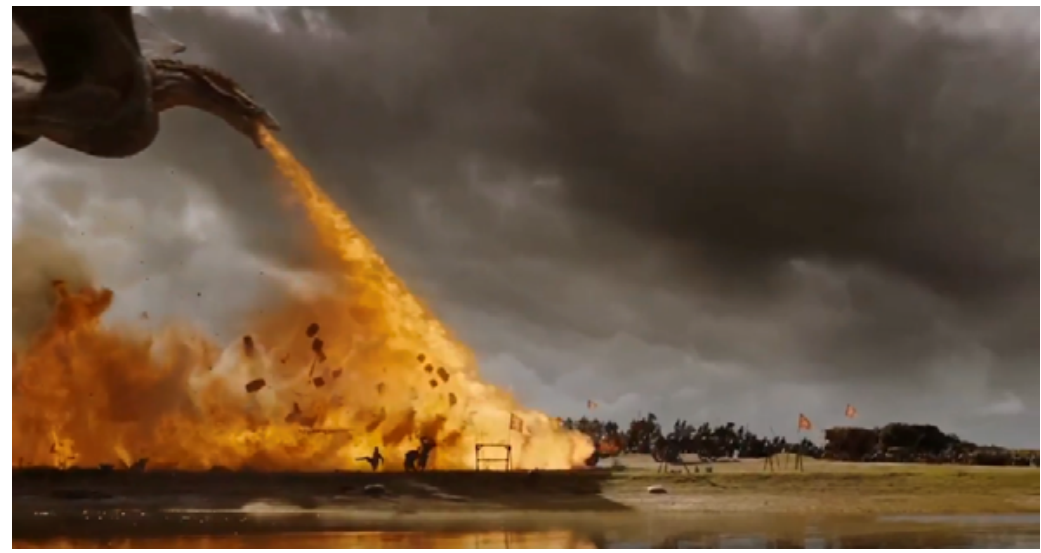

Nota. Dragão ataca os exércitos dos Lannisters e seus aliados; clímax do processo catártico ao proporcionar o sentimento de satisfação à audiência, que se identifica com os heróis; nesse caso, a crueldade que representa a queima de seres humanos vivos estaria moralmente justificada. Imagem da série.

Ambos os exemplos aqui analisados desenvolvem o mesmo processo catártico - da emulação do medo/raiva à satisfação com o alívio proporcionado pelo triunfo do herói - e envolvem os mesmos arquétipos principais - nas sequências analisadas, predominam nos protagonistas os arquétipos do herói e do monstro, conforme o sintetizado na Figura 11. O esquema ajuda a visualizar o que 
descrevemos antes, isto é, como as imagens arquetípicas variam, sendo inclusive opostas - a imagem do nativo/selvagem (Apache), que preenche o arquétipo do monstro em No Tempo das Diligências (Ford, 1939), no caso de Game of Thrones (Benioff et al., 2011-2019), os nômades Dothraki, preenche a imagem do herói -, mostrando o impacto que contexto social e histórico tem nas imagens arquetípicas.

Figura 11

Relação entre catarse, arquétipos e imagens arquetípicas

NO TEM PO DAS DILIGËNCLAS

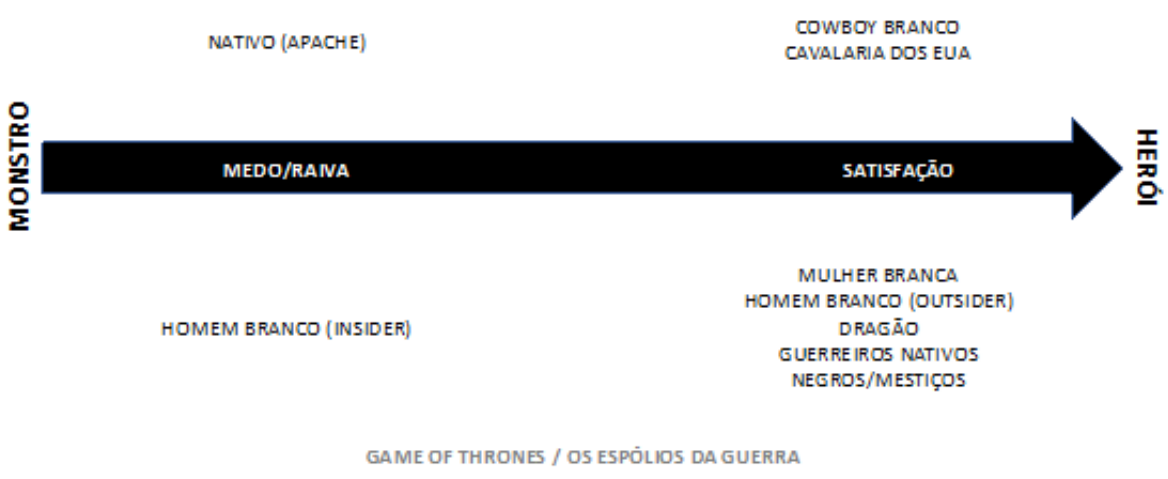

Nota. Elaborado pelo autor.

É importante ressaltar que uma série televisiva com vários episódios e várias temporadas, como é o caso de Game of Thrones (Benioff et al., 2011-2019), tem a possibilidade de desenvolver seus protagonistas psicológica e sociologicamente de forma muito mais completa do que um filme com duração de 95 minutos, como é o caso de No Tempo das Diligências (Ford, 1939). Ainda assim, a relação entre arquétipos e os sentimentos por eles acionados - que é o que nos interessa analisar aqui - mostra convergências nos dois tipos de narrativas.

\section{CONCLUSÕES}

Os exemplos aqui estudados mostram que a oposição arquetípica herói-monstro - uma das variações do dualismo bem versus mal - tem um papel significativo na catarse estética. A empatia e a identificação do espectador com a imagem que usa para preencher o arquétipo do herói e a aversão à imagem 
que usa para preencher o arquétipo do monstro constituem o elemento básico do processo catártico nas sequências analisadas.

Os sentimentos gerados durante as sequências catárticas - como raiva, medo e satisfação - estão conectados, assim, aos arquétipos em ação nas cenas que as compuseram. É importante frisar, conforme a comparação dos dois exemplos evidenciou, que são os arquétipos que operam como gatilhos emocionais na catarse, e não os personagens, suas imagens ou o contexto sócio-histórico. Ao preencher mentalmente um arquétipo com determinado personagem, imagem e/ou elemento, o espectador estabelece os sentimentos potenciais que poderão ser acionados em cenas decisivas na narrativa com a participação daqueles. Também, como foi observado, o contexto sócio-histórico pode até inverter o papel dos personagens, mas os arquétipos e os sentimentos por eles gerados permanecem os mesmos.

Entendemos, por fim, que este estudo inicial sinaliza que pode ser promissor analisar cenas catárticas em filmes e séries de diferentes gêneros para se verificar, com maior amplitude, a hipótese aqui desenvolvida: de que o arquétipo - especialmente o do herói (ou a oposição arquetípica herói-monstro) -, dada sua universalidade e atemporalidade e por ser repositório de potenciais emoções, exerce o papel central na geração de sentimentos na audiência durante o processo de catarse estética nas narrativas audiovisuais, independentemente das imagens a ele associadas ou do contexto sócio-histórico em que se insere. $\mathbf{M}$

\section{REFERÊNCIAS}

Antunes, F. S., Jr. (2016). A retórica midiática como gatilho de emoções arquetípicas. Mídia e Cotidiano, 10(10), 210-225. https://doi.org/10.22409/ ppgmc.v10i10.9803

Aristóteles (2018). Poética. Fundação Calouste Gulbenkian. (Trabalho original publicado em 350 a.C.)

Benioff, D., Weiss, D. B., Strauss, S., Doelger, F., Caulfield, B., Cogman, B., Sapochnik, M., \& Nutter, D. (Produtores Executivos). (2011-2019). Game of thrones [Série de televisão]. Television 360; Grok! Television; Generator Entertainment; Startling Television; Bighead Littlehead.

Benioff, D. (Roteirista), Weiss, D. B. (Roteirista), \& Shakman, M. (Diretor). (2017, 30 de julho). Os espólios da guerra [The spoils of war] (Temporada 7, Episódio 4) [Episódio de série de televisão]. In D. Benioff, D. B. Weiss, S. Strauss, F. Doelger, B. Caulfield, B. Cogman, M. Sapochnik, \& D. Nutter (Produtores Executivos), Game of thrones. Television 360; Grok! Television;

Generator Entertainment; Startling Television; Bighead Littlehead.

Campbell, J. (1997). O herói de mil faces. Cultrix; Pensamento. 
Coogan, P. (2009). The definition of the superhero. In J. Heer \& K. Worceste (Eds.), A comics studies reader (pp. 77-93). University Press of Mississippi. Damásio, A. (2012). O erro de Descartes: Emoção, razão e o cérebro humano. Companhia das Letras. https://amzn.to/3qDGgUV

Dunleavy, T. (2018). Complex serial drama and multiplataform television. Routledge. https://doi.org/10.4324/9781315682310

Durand, G. (2002). As estruturas antropológicas do imaginário. Martins Fontes. Durand, G. (2013). De la mitoctítica al mitoanálisis: Fíguras míticas y aspectos de la obra. Anthropos.

Ekman, P. (2011). A linguagem das emoções. Lua de Papel.

Ford, J. (Diretor). (1939). No tempo das diligências [Stagecoach] [Filme]. Walter Wanger Productions, Inc.

Ford, J. (Diretor). (1956). Rastros de ódio [The searchers] [Filme]. C. V. Whitney Pictures.

Freire, A. (1979). Hermenêutica tradicional da catarse aristotélica. Revista Portuguesa de Filosofia, 35(3), 1-30.

Jauss, H. R. (1974). Levels of identification of hero and audience. New Literary History, 5(2), 283-317. https://doi.org/10.2307/468397

Jung, C. G. (2014). Os arquétipos e o inconsciente coletivo. Vozes. (Trabalho original publicado em 1976)

Mauss, M., \& Hubert, H. (2005). Sobre o sacrifício. Cosac Naify.

McKee, R. (2010). Story: Substance, structure, style, and the principles of screenwriting. Harper Collins. https://amzn.to/2UNp8Qz

Mittel, J. (2012). Complexidade narrativa na televisão norte-americana contemporânea. MATRIZes, 5(2), 29-52. https://doi.org/10.11606/issn.1982-8160. v5i2p29-52

Moore. A., \& Gibbons, D. (1988-1989). Watchmen (Vol. 1-12). Abril.

Neumann, E. (1999). A grande mãe: Um estudo fenomenológico da constituição feminina do inconsciente. Cultrix.

Paskow, A. (1983). What is aesthetic catharsis? The Journal of Aesthetics and Art Criticism, 42(1), 59-68. https://doi.org/10.2307/429947

Santoro, F. (2007). Sobre a estética de Aristóteles. Viso Cadernos de Estética Aplicada, 1(2), 1-13. http://doi.org/10.22409/1981-4062/v2i/36

Schaper, E. (1968). Aristotle's catharsis and aesthetic pleasure. The Philosophical Quarterly, 18(7), 131-143. https://doi.org/10.2307/2217511

Vogler, C. (2015). A jornada do escritor: Estrutura mítica para escritores. Aleph.

Artigo recebido em 11 de novembro de 2020 e aprovado em 17 de abril de 2021. 